\title{
RAPESEED (Brassica napus L.) AND ITS PROSPECTIVE USEAGE IN POULTRY DIET (review)
}

\section{T.A. EGOROVA, T.N. LENKOVA}

All-Russian Research and Technological Poultry Institute, Federal Agency of Scientific Organizations, 10, ul. Ptitsegradskaya, Sergiev Posad-11, Moscow Province, 141300 Russia, e-mail eta164@yandex.ru, dissovet@vnitip.ru, vnitip@vnitip.ru

Received August 19, 2014

\section{Abstract}

A recent trend in the world's crop production is an intensified cultivation of oil-yielding crops, particularly rape (Brassica napus), as a source of vegetable oils and valuable protein for animal nutrition. Rape is especially promising crop for climatic and soil conditions of the Russian Federation as it can be grown almost all over the country. Energy content in rape is 1.7 to 2.0 times as much as in cereals, and 1.3 to 1.7 times as much as in legumes. Amino acid composition in rape proteins is well-balanced, and the lysine level is almost similar to that in soy, while the methionine, cystine, $\mathrm{Ca}$ and $\mathrm{P}$ levels are much higher. In animal farming and poultry the rape seeds, as well as rape oilcake, meal and oil are used. In rape seeds the fat content is $40 \%$, the protein level reaches $23 \%$ and cellulose amounts to $4 \%$. However, their use in hen's feeding is limited due to poor digestibility of seed shells and specific composition. In rape oil the level of unsaturated fat acids is high, i.e. $60.0-70.0 \%$ for oleic acid, $23.3 \%$ for linoleic acid and $10.5 \%$ for linolenic acid which can regulate biosynthesis of prostaglandins thus effecting positively the reproductive function. Biological, energy and protein value of rape seed meal is high and similar to that of high-protein feed-stuff of animal origin. The rape meal is rich in choline, biotin, folic acid, riboflavin, thiamin and minerals compared to soy though some of these elements are less available. The rape oilcake contains fats at $8.75 \%$, cellulose at $12.0 \%$ and proteins at $32.0 \%$ on the average. These proteins are enriched with irreplaceable amino acids, and the lysine and $\mathrm{S}$ containing amino acids levels amount to 5.7 and $5.0 \%$, respectively. Anti-nutritive compounds including erucic acid and glucosinolates are the factors limiting use of rapeseed and related products in animal nutrition. In the article the methods for improving nutritive value of rapeseed products are discussed, including genetic selection of rape, thermal processing and supplementation of diets with enzyme preparations. Classification of rape cultivars is considered with regard to fatty acids and glucosinolates content in seeds («++», «0+», «+0», «00», «000»). Supplementation of broiler diets with rapeseed cake containing $0.41 \%$ of isothiocyanates and $0.25 \%$ of erucic acid together with a designed enzyme preparation MEC-CP-4 (Russia) is proposed as an effective feeding technology. In poultry this additive allows to use fodder containing $7.5 ; 10.0$ and $15.0 \%$ of rapeseed oilcake in case it is supplemented with 500, 750 and 1000 ppm MEC-CP-4, respectively.

Keywords: rape, mixed feeds, broilers, health and productivity of poultry, glucosinolates, erucic acid.

Adequate balanced feeding is a basis for efficient poultry production [1]. At present, the poultry diet usually includes $65-80 \%$ of grain crops (corn, wheat, barley, oat, millet). According to the All-Russian Research Institute for Fodder Crops (Moscow Region), over $70 \%$ of gross grain harvest in Russia is used as food for farm animals and birds, mostly for poultry. The need to reduce the amount of grain in finished feeds has resulted in greater attention to different byproducts [2-4].

Using non-conventional feeds is one of affordable methods to reinforce the poultry food resources [5]. Nowadays, with the lack of primary raw materials in the finished feed industry, mainly sources of protein, this becomes especially important. The reduction of the protein content in finished feeds below the existing standards has an adverse effect on poultry productivity and the 
production cost $[6,7]$.

The current situation in the domestic agriculture requires scientific approach to solving the problem of protein by using oil-yielding crops, including rape and rape products, in poultry feeds $[8,9]$. In recent years, this crop along with soy and sunflower is becoming more and more valuable.

Rape holds a special place in the agricultural production. It is an alternative source of organic fertilizers. In rape, 10-15 tons of roots, leaves, and straw are returned to the soil as dry matter. According to research of the Russian scientists, the amount of root residues per 1 ha of rape plantings is 60 centners, which is 6-7 times more compared to grain crops and 2 times more compared to clover. Moreover, this crop prevents soil erosion, infiltration of nitrogen compounds into groundwater and therefore reduces pollution of soil and water. Formerly a purely agricultural crop, rape is becoming a strategic crop making it possible to produce not only food for people and animals but also renewable industrial raw materials widely used in transport and many other industries such as food, metallurgy, paint, soap, leather, textile industry, etc. Therefore, it is called a crop of the future $] 10,11]$.

The rape cake and meal make a valuable protein feed which will enable to reduce the dependence on the imported sources of protein for animals [12, 13].

The results of research on the nutritive value of rapeseed meal were first published in Germany in 1872. But soon after that, information appeared that the rape feeds contain toxic components which disturb metabolism and accessibility of nutritive and biologically active substances, have an adverse effect on health and reproductive functions of animals, and can accumulate in their bodies and farm products (meat, milk, eggs) [14].

The rape feeds contain different amounts of harmful (anti-nutritive) compounds depending on the species, cultivation conditions, vegetation phase [15]. According to their action, they can be divided into polyphenol compounds, which complicate digestion and further use of protein; phytic acid and glucosinolates, the compounds reducing solubility or metabolism of minerals; erucic acid, which causes vascular disorders, lipidic infiltration of skeletal muscles and myocardium, hepatic cirrhosis. The glucosinolates and erucic acid contained in rape limit the use of protein [16-18].

Of all the harmful substances in rape, glucosinolates, which belong to the thioglycoside group containing sulfur compounds, should be put into first place $[19,20]$, with progoitrin being the most important of all. The glucosinolates per se are not hazardous toxicants [21, 22]. They are highly water-soluble glucosides, which remain in cake and meal after pressing or extraction of oil from rape. The enzyme myrosinase contained in the rape and other plants, and some microorganisms of gastrointestinal tract of animals cleave glucosinolates with the release of thiocyanates, isothiocyanates, goitrin and other substances [21, 23].

The glucosinolates are hydrolyzed in the body with the formation of isothiocyanates and nitriles, toxic for the thyroid gland, binding iodine substances, which results in hypothyroidism with metabolic disorders, hyperplasia of follicular epithelium; at that, productivity of animals decreases sharply, and decomposition of the fetus, abortions, dead births are possible. Besides, hepatotoxic effect with hemorrhages of liver can be noted [24-27]. Rape seeds, cake and meal should be noted to contain about $25 \%$ of glucosinolates as isothiocyanates, their most toxic form. The maximum permissible concentrations (MPC) of glucosinolates in diets of farm livestock per $1 \mathrm{~kg}$ of live weight are no more than $5 \mathrm{mg}$ in pig and poultry feeds, no more than $10 \mathrm{mg}$ for ruminants, and $50 \mathrm{mg} / \mathrm{kg}$ in finished feeds [24].

The second anti-nutritive substance of rape is sinapine, which the intes- 
tine microorganisms transform into choline. In the bird intestine it can be transformed into another harmful substance, the trimethylamine, giving bird eggs a fishy taste. Moreover, once formed, trimethylamine does not get decomposed in the presence of sinapine since the latter inhibits trimethyloxidase, which catalyzes trimethylamine decomposition. Seeds of rape as well as other cruciferous plants (mustard, bittercress, radish) contain glycosides, the sinigrin, sinalbin, gluconapin and neoglucobrassicin destructing the mucous membrane of gastrointestinal tract and pulmonary tissue (in case of steam inhalation). When reabsorbed from the gut into the blood, they excite the central nervous system, and disturb the function of the heart and kidneys [24, 25, 28].

Oil of uncultivated rape varieties may contain of up to $42 \%$ of polyunsaturated fatty erucic acid $\left(\mathrm{C}_{22}\right)$, which is considered a harmful substance [29]. It causes adipose infiltration of skeletal and cardiac muscles, liver hemorrhages and slows down oxidation processes in the mitochondria of the myocardium [21]. The serotinal varieties of rape recommended as a feed for pigs and poultry contain small quantities of erucic acid.

The content of anti-nutritive compounds in rape and rape products should be controlled [30].

Thermal reduction of toxic content in the rape feeds such as steaming and boiling are the most widely used methods making mirosinase enzyme inactive. Quite an efficient method for the neutralization of harmful substances in the rapeseed cake is a two-stage extraction with boiling water resulting in the considerable decrease in the content of toxic substances but without any adverse effects on the protein nutritional value of the feed [31]. Another method for the neutralization of harmful substances in the rape feeds which can be used at any farm is microbiological one. It involves rapeseed cake silaging together with carbohydrate-rich fodder (potato, beet, herbage, corn). As a result of lactic fermentation, the content of anti-nutritive compounds decreases by 60-90\% [31].

However, neither of the above methods has been commercially applied, therefore methods for the inactivation of glucosinolates need further development.

The simplest method to reduce the effect of anti-nutritive factors is a selective search for genotypes of rape with a reduced content of glucosinolates [32]. Thus, genotypes with a 10 -fold reduction in the glucosinolate content in seeds as compared with other known varieties were detected among the spring rape plants of Bronovski variety (Poland) as early as 1967. As a result, a large number of high-yielding varieties of rape with low (up to $30 \mu \mathrm{mol} / \mathrm{g}$ ) and medium (up to $60 \mu \mathrm{mol} / \mathrm{g}$ ) content of these substances were bred [33].

In recent years, the rapeseed cake and meal have started competing with soybean ones in the diets of farm livestock owing to the success of the breeders and improvements in the production technology [34-37].

Canada was the first to start research into the plant selection aimed at the improvement of oil-yielding crops in 1970s, followed by France, the German Federal Republic, and Sweden. The research was subsequently continued in the German Democratic Republic, the People's Republic of Poland, Denmark, the USSR, the People's Republic of Hungary, the Czechoslovak Socialist Republic, and Belgium. Initially, high-yielding varieties of rape with increased content of oil in the seeds and frost-resistant winter varieties were bred. Further, the researchers focused on the reduction of the content of erucic acid and glucosinolates in the seeds.

The level of erucic acid is estimated as the percentage from the total content of fatty acids in the seed oil. The glucosinolate content $(\%, \mathrm{mg} / \mathrm{g}$ or $\mu \mathrm{mol} / \mathrm{g})$ is determined for dry fat-free matter. The amount of glucosinolates in the rape seeds has been found to vary depending on the weather conditions, the location 
of the field and other factors [21]. Based on the content of fatty acids and glucosinolates in the seeds, four types of rape varieties and hybrids can be currently distinguished at the global market.

Traditional varieties («++») are characterized with high content of erucic acid (45-55\%) and glucosinolates $(100-200 \mu \mathrm{mol} / \mathrm{g})$. They are used as a green fertilizer and to produce bio-fuel but the cake cannot be fed to animals. The varieties with low content of erucic acid (less than $5 \%$ ) and high content of glucosinolates $(80-95 \mu \mathrm{mol} / \mathrm{g})$ were initially called «low-erucic», or «one zero varieties» $(\ll 0+»)$. Subsequently this limit was lowered and the varieties with seeds containing less than $2 \%$ of erucic acid were included into «0+» group. They are used to produce highly valuable edible oil; the meal and cake can be fed to animals in limited amounts. The rape «t0» varieties with high content of erucic acid (47\%) and low in glucosinolates (less than $20 \mu \mathrm{mol} / \mathrm{g}$ ) are only used to produce industrial oils and biodiesel, and the cake and meal are used as high-protein feeds. The rapeseed varieties low in erucic acid (0-2\%) and glucosinolates (less than $20 \mu \mathrm{mol} / \mathrm{g})$ are called «double-zero varieties» $(« 00 »)$. They are used to produce quality oil and protein-rich feeds [38]. The weight fraction of glucosinolates in the seeds of the national «00» varieties does not exceed $1 \%$.

Current research is focused on further improvements of the rape seed quality, on breeding rape varieties and hybrids with the content of oleic acid of up to $85 \%$, palmitic acid of up to $10-20 \%$ as well as with very low content of erucic acid. This will make it possible to use rape seed oil not only as food but also in the production of detergents, paints, cosmetics, fuel and lubricants, and hydraulic fluids.

Breeding «000» varieties of rape with yellow seeds (low not only in erucic acid, glucosinolates but also in fiber content) will improve the quality of cake and meal used as feeds for farm animals and poultry [21].

As of 2006, 53 «double-zero» varieties of spring and 20 «double-zero» varieties of winter rape have been approved for the use in Russia, including 11 and 14 foreign ones respectively. Seed quality is determined in accordance with the new state standard for rape seeds adopted in 2006 (GOST R 52325-2005 «Seeds of agricultural plants. Varietal and sowing characteristics. General specifications»), in which the content of anti-nutritive compounds in first generation seeds is strictly regulated. Thus, the amount of erucic acid in the original and elite seeds must not exceed $1 \%$ (instead of $3 \%$ according to the previous GOST), and the amount of glucosinolates must be not more than $15 \mu \mathrm{mol} / \mathrm{g}$ (instead of $2 \%$, corresponding to the $46 \mu \mathrm{mol} / \mathrm{g}$ for rape, and $3 \%$, or $75 \mu \mathrm{mol} / \mathrm{g}$, for winter cress).

Rape is a promising and practical source to replenish feed protein. By the yield of nutrients per unit area, its nutritional and feed advantages, rape is superior to many other crops [39]. The metabolizable energy content in rape is 1.7 to 2.0 times higher than in cereals, and 1.3 to 1.7 times higher than in legumes (pea, soy). Rape proteins present a well-balanced amino acid composition, with lysine level almost similar to that in soy and much higher levels of methionine, cystine, $\mathrm{Ca}$ and $\mathrm{P}$. However, the digestibility of the rape nutrients is lower compared with other feeds [40-42].

The rape feeds make it possible to balance the diets of cattle and poultry on protein and metabolizable energy content. The composition of rape protein and soy protein as well is close to animal proteins but the production cost of 1 ton of rapeseed protein is 5-10 times lower compares to animal protein [10, 43].

Both rapeseed and rapeseed products such as cake, meal and oil, are used as feeds for farm animals and poultry [8, 44]. Cake is the remains after the extraction of oil using the expeller press; meal is produced after the extraction of 
oil using proper solvents.

The fat content in rape seeds can reach $40 \%$, the crude protein content is $23 \%$ and the fiber content is $4 \%$ [45]. The results of the chemical analysis demonstrate high energy value of this product. However, it has found a limited use in chicken feeds because of poor digestibility of seed shells and the specifics of their composition [46, 47]. Rape seeds are mostly used for commercial production of oil. They contain proteins, carbohydrates, minerals, vitamins, phosphorus compounds determining the value of oil extraction residues, e.g. cake and meal [8].

Rape oil is considered one of the best vegetable oils [48]. It is high in unsaturated fat acids (oleic acid of 60.0-70.0 \%, linoleic acid of $23.3 \%$ and linolenic acid of $10.5 \%$ ), which control biosynthesis of prostaglandins and have a positive effect on the reproductive function of animals.

Biological, energy and protein values of rapeseed flour are high, similar to those of high-protein feeds of animal origin. It contains less lysine but it is considerably richer in cystine and methionine, contains more choline, thiamin, microelements as compared with soybean meal.

Introduction of flour from rape seeds, cake and meal into the grain mixture considerably increases its nutritional value and makes it possible to use finished feeds in an optimal way $[8,14,39]$. The feed value of the rapeseed products depends on the product itself, the production technology, the chemical composition, the amount of anti-nutritive compounds [49].

On average, rapeseed meal contains $35.5 \%$ of crude protein, $2.5 \%$ of crude fat and $12.0 \%$ of fibers. The amino acid composition is similar to that of other types of vegetable meals. By the content of essential amino acid lysine, it is inferior to soybean meal but superior to sunflower meal. As compared with other types of meal, the rapeseed meal contains less arginine and tyrosine [41, 45]. A $100 \mathrm{~g}$ portion of rapeseed meal contains 200-225 kcal of metabolizable energy (depending on the amount of sugar, starch, and residual fat) [50].

Rapeseed meal is usually not considered a source of vitamins when it comes to diets, but it is higher in choline, biotin, folic acid, riboflavin and thiamin than the soybean meal.

Rapeseed meal contains 10-20\% less metabolizable energy than soybean meal. This difference can be explained by larger amounts of fibers. It is richer in mineral salts, but the phytic acid and fibers reduce the availability of phosphorus, calcium, magnesium, zinc and some other minerals when fed to poultry. Furthermore, crude fibers reduce the availability of copper and manganese. Nevertheless, rapeseed meal can be the best source of available calcium, iron and manganese, phosphorus, selenium and magnesium, than soybean meal, with the latter being richer in copper, zinc and potassium [49].

Adding rapeseed meal with low content of glucosinolates in finished feeds for farm animals and poultry is one of the key factors for the intensification of animal husbandry and poultry production in other countries [51-53].

Rapeseed cake is not inferior to sunflower cake by its nutrition value and is superior to it by the content of some essential amino acids [13]. It contains $32.0 \%$ of proteins, $8.75 \%$ of fats, and $12.0 \%$ of fibers on average [45]. The feed value of the rapeseed cake is $30 \%$ higher than the value of meal due to the higher content of fat (by $8 \%$ ) and better digestibility of organics $(72.5 \%$ compared with $66.2 \%)$. In terms of minerals, the cake is higher in iron, copper and cobalt but lower in sodium and manganese. The cake is richer in vitamins $\mathrm{E}, \mathrm{D}$ and $\mathrm{B}_{5}$.

Rapeseed cake contains less protein than cakes of other crops, and it is only sunflower cake that is superior to it by the amount of fibers. The protein 
composition in the rapeseed cake includes many essential amino acids. Rapeseed cake is rich in lysine (5.7\% compared with $6.5 \%$ in soybean meal) and sulfur containing amino acids $(5.0 \%)$ [14].

Rapeseed cake is a good supplier of minerals. It is superior to soybean cake by the content of magnesium, copper and manganese, with the availability of calcium being at $68 \%$, phosphorus at $75 \%$, magnesium at $62 \%$, manganese at $54 \%$, copper at $74 \%$, and zinc at $44 \%$.

In case of 1 ton of rapeseed meal added to 7-8 tons of grain fodder it balances the protein content [54]. Relatively low prices of rapeseed meal and cake compared with other traditional vegetable protein feeds in Russia (soybean and sunflower cakes and meals) make them an attractive option in terms of reduction of the cost of the diets.

With high digestibility of nutrients $[55,56]$, rape feeds proved to be suitable for all species and age groups of farm animals and poultry.

Data available in literature on the application of rape in poultry farming are often controversial [57-60] since the results of research depend on a lot of factors, namely on plant varieties, poultry species, growing conditions, feeding protocol, etc. [61]. It should be noted that the optimum dosages suggested by foreign researchers do not guarantee positive results in the conditions of national poultry farms [62-64].

A ways to enhance digestibility and the use of nutrients in finished feeds, including alternative ones, is using enzyme preparations [65-69]. Enzyme preparations have been found to promote specific enzyme activity in the bird digestive tract increasing hydrolysis of proteins, fats and carbohydrates [70, 71].

In response to a vital for Russia problem of substituting corn and soy with local feeds, the Lekbiotekh Research and Technology Center (Russia) created MEC-CP-4, a new multi-enzyme complex with protease, xynalase, $\beta$ glucanase, pectin-lyase and $\alpha$-galactosidase activity.

Our research showed that the maximum possible dosage of rapeseed cake throughout the entire period of broiler growing could be 7.5-10.0\% [72-74]. Enrichment of finished feeds containing rapeseed cake with an enzyme preparation enhances the use of nutrients of the feed and improves productive qualities of broilers [75, 76]. Moreover, the enzyme has no direct impact on the antinutritive compounds, yet mitigates their adverse effect on chickens. To enhance productivity of broilers and the efficiency of finished feeds containing 7.5, 10.0 and $15.0 \%$ of rapeseed cake, we recommend supplementing them with MECCP-4 in the ratio of 500, 750 and 1,000 g per 1 ton of feed, respectively.

Thus, despite extensive experience in the application of rape products in animal husbandry in other countries, there is little scientific research on this topic in our country. Rape is a promising and practical source to replenish feed protein, a valuable feed crop with a high content of proteins, carbohydrates and fats. By the yield of nutrients per unit area, rape cultivated for grain exceeds grain crops. Glucosinolates and erucic acid in rape seeds are the main factors limiting their use as poultry feed. The permissible amount of rape seeds and rapeseed products in the diet of commercially grown chicken and broilers is up to $5 \%$ of the feed weight. The methods improving the nutritive value of rape include selection, seed thermal processing (boiling, steaming, double-stage extraction with hot water, etc.) as well as the use of enzyme preparations. The most promising are «00» varieties, the amount of erucic acid in the oil of which does not exceed $2 \%$, and the weight fraction of glucosinolates is below $1 \%$. In this case, enzyme preparations give positive results. We demonstrated that if $7.5 \%$ of rapeseed cake is introduced into the feed, the dose of MEC-CP-4 enzyme preparation should be $500 \mathrm{~g}$ per ton, for $10 \%$ the dose increases to $750 \mathrm{~g}$ per 
ton, for $15 \%$ it is up to $1,000 \mathrm{~g}$ per ton of the feed. The undertaken research will promote a wider use of rapeseed cake in finished feeds for poultry and reinforce the fodder base of the industry.

\section{R E F E R E N C ES}

1. Po no mare n k o Yu.A., F is i n i n V.I., Eg o rov I.A. Korma, biologicheski aktivnye veshchestva, bezopasnost' [Fodder, bioactive substances, safety]. Minsk-Moscow, 2014.

2. Fisinin V.I., Kalashnikov V.V., Draganov I.F., Amerkhanov Kh.A., D e g t y a rev V.P. Novoe $v$ kormlenii broilerov [A new approach to feeding the broilers]. Moscow, 2012.

3. F is in in V.I., Eg o rov I.A., D raga nov I.F. Kormlenie sel'skokhozyaistvennoi ptitsy [Poultry feeding]. Moscow, 2011.

4. Chikov A.E., Ko non e n k o S.I. Puti resheniya problemy proteinovogo pitaniya zhivotnykh [How to improve the protein nutrition of farming animals]. Krasnodar, 2009.

5. Egorov I.A., Le nkova T.N., Rozanov B.L., Andrianova E.N., Okoelova T.M., Egorova T.V., Ignatova G.V., Kharlamov K.V., Prisyazhnaya L.M., G u 1 y u sh i n S.Yu., S o k o 1 o va T.N., R y s e va N.P., E 1 i z a rova E.V., Ve reshchagina E.N., Men'shenin I.A., Egorova T.A., Zevakova V.K., Ly$\mathrm{ch}$ ak A.V., Grebneva I.V., Ig n t ovi ch L.S. Nastavleniya po ispol'zovaniyu netraditsionnykh kormov $v$ ratsionakh ptitsy [Instruction for use of non-conventional feed in poultry diet]. Sergiev Posad, 2010: 45.

6. Fis i n i n V., Eg o rov I. Ptitsevodstvo, 2011, 3: 7-9.

7. F i s i n i n V.I. Vestnik RASKHN, 2010, 1: 9-12.

8. Li s its y $\mathrm{n}$ A.N., G rig o r' e va V.N., Li s h a e va L.N. Vestnik Vserossiiskogo nauchnoissledova-tel'skogo instituta zhirov (St. Petersburg), 2013, 1: 5-12.

9. A r t e m' e v I.V., K a r p a c h e v V.V. Agrarnaya nauka, 2006, 4: 18.

10. Ku rbanov S., Is ma i 1 ov I., N i m a tu la e v N. Agrarnaya nauka, 2009, 2: 27-31.

11. K u r b a n o v S.A Problemy razvitiya APK regiona, 2010, 1(1): 33-36.

12. Po no mare n k o Yu. Kombikorma, 2013, 4: 57-59.

13. E g o r o v a T.A. MEK-KP-4 v kombikormakh dlya broilerov, soderzhashchikh rapsovyi zhmykh. Kandidatskaya dissertatsiya [MEK-KP-4 in the combined fodder with rapeseed cake fed to broilers. PhD Thesis]. Sergiev Posad, 2011.

14. Novoe v kormlenii sel'skokhozyaistvennykh zhivotnykh /Pod redaktsiei M.F. Tomme [Improved nutrition for farm animals. M.F. Tomme (ed.)]. Moscow, 1956: 75-80.

15. Ciska E., Kozłowsk a H. Glucosinolates of cruciferous vegetables. Polish J. Food Nutr. Sci., 1998, 48: 5-22.

16. Gu $1 \mathrm{hermet}$ R. Utilization du tourteau de colza a faible teneur eu glucosinolates par le veau serve pecocement. Bull. Techn. S.R.Z.V. Theix. INRA, 1986, 64: 21-23.

17. S i mova J. Glukosinolaty repke a toxicita jejich stepnyck produktu. Postl. Vyroba, 1984, 30(4): 399-404.

18. S h p a k ov A.S., F i rtse v A.I., G a g a n o v A.P. Ispol'zovanie rapsa v kormlenii sel'skokhozyaistvennykh zhivotnykh (rekomendatsii) [Rape in the diet of farm animals: recommendations]. Moscow, 2004: 10-33.

19. Tripathi M.K., M ishra A.S. Glucosinolates in animal nutrition: a review. Anim. Feed Sci. Technol., 2007, 132: 1-37 (doi: 10.1016/j.anifeedsci.2006.03.003).

20. Maws on R., Heany K., Zdunczyk Z., Kozlowska H. Rapeseed meal glucosinolates and their antinutritional effects. 2. Flavor and palatability. Die Nahrung, 1993, 37: 336-344.

21. D e m' y a $\mathrm{nchuk}$ G.T. Ptitsevodstvo, 2002, 8: 10-12.

22. Jons s o n R., Uppstom B. Quality breeding in rapeseed. In: Research and results in plant breeding. Stockholm, 1986: 173-184.

23. A l e k s a n d rov Yu.A. Kormovye toksikozy sel'skokhozyaistvennykh zhivotnykh [Feed-caused toxicosis in farm animals]. Ioshkar-Ola, 2000: 88.

24. S o r e n s e n H. New methods of quantitative analysis of glucosinolates. Series: World crops: production, utilization, description. Springer, 1981, V. 5: 107-126.

25. Underchill F.W., Wet ter L.R., Ch isholm M.D. Biosyntesis of glucosinolares. Biochem. Soc. Sump., 1973, 38: 303-326.

26. Ko z he my ak a N. Ptitsevodstro, 1992, 5: 20.

27. C a m p b 11 L.D., S 1 o m i n ski B.A. Feeding quality of very low glucosinolate canola. Proc. 12th Western Nutrition Congr. Winnipeg, Manitoba, 1991: 245-252.

28. Khagali F., Slominski B. Factors that affect the nutritive value of canola meal for poultry. Poult. Sci., 2012, 91: 2564-2575 (doi: 10.3382/ps.2012-02332).

29. Thanaseelaan V., Niswanathan K., Chandrasekaran D., Prabakaran R., 
Chellapandian M. Chemical composition, amino acids, minerals and anti nutritional factors of rapeseed meal. Journal of Veterinary and Animal Science, 2007, 3: 101-105.

30. Cladinin T. The effects of high- and low-erucic acid rapeseed oil on energy metabolism in chicks. Proc. $5^{\text {th }}$ Int. Rapeseed Conf. Malmö, 1979, V. 2: 279-283.

31. G a r e e v R.G. Raps - kul'tura vysokogo ekonomicheskogo potentsiala [Rapeseed as an economically valuable crop]. Kazan', 1996.

32. Robbelin G. Variation in rapeseed glucosinolates and breeding for improved meal quality. In: Brassica crops and wild allies: biology and breeding. Tokyo, 1980: 285-299.

33. Milashchenko N.Z., Abramov V.F. Tekhnologiya vyrashchivaniya $i$ ispol'zovaniya rapsa $i$ surepitsy [Rapeseed and colza cultivation and use]. Moscow, 1989: 223.

34. Le n k ova T.N. Egorova T.A. Materialy XVII Mezhdunarodnoi konferentsii VNAP «Innovatsionnye razrabotki i ikh osvoenie v promyshlennom proizvodstve» [Proc. XVII Int. Conf. «Innovations and their use in commercial poultry»]. Sergiev Posad, 2012: 222-223.

35. Le n k ova T., Eg o rova T. Kombikorma, 2011, 2: 68-70.

36. F a l a le e va E.V., L o s h k o m o i n i k ov I.A. V sbornike: Kormovye resursy Zapadnoi Sibiri $i$ ikh ratsional'noe ispol'zovanie [In: Fodder resources of Western Siberia and their use]. Omsk, 2005: 151-162.

37. Shmakov P., Falaleeva E., Mal'ts eva N., Loshkomoinikov I. Ptitsevodstvo, 2007, 8: 14-15.

38. Faruga A. Zum einsatz von rapsextraktionsschrot der winterraps - doppelqualitätssorte «Start» in der ernährung von schweine. Getreidewirtschaft, 1984, 11: 248-249.

39. J a nocha A., Klocek B., Osek M. Evaluation of diets for broilers containing different levels of seeds of double low oilseed rape. Rośliny Oleiste, 1994, 15: 199-206.

40. C i u r e s c u G. Efficiency of soybean meal replacement by rapeseed meal and/or canola seeds in commercial layer diets. Archive Zootechnica, 2009, 12: 27-33.

41. Rezvani M., Kluth H., Bulang M., Rodehutscord M. Variation in amino acid digestibility of rapeseed meal studied in caecectomised laying hens and relationship with chemical constituents. Br. Poult. Sci., 2012, 53: 665-647 (doi: 10.1080/00071668.2012.729130).

42. Toghyani M., Mohammadsalehi A., Gheisari A., Tabeidian S. The effect of low-glucosinolate rapeseed meal in diets with multi-enzyme supplement on performance and protein digestibility in broiler chicks. J. Anim. Feed Sci., 2009, 18: 313-321.

43. Talebali H., Farzinpour A. Effect of different levels of full-fat canola seed as a replacement for soybean meal on the performance of broiler chickens. Int. J. Poultry Sci., 2005, 4: $982-985$.

44. Szymeczko R., Topolinski T., Burlikovska K., Piotrowska A., Boguslawska-Tryk M., B laszyky J. Effects of different livels of rape seeds in the diet on performance, blood and bone parameters of broiler chickens. J. Cent. Eur. Agr., 2010, 11(4): 393-400.

45. Fisinin V.I., Egorov I.A., Lenkova T.N., Okolelova T.M., Ignatova G.V., M a nukyan V.A., Shevyakov A.N., Egorova T.V., Andrianova E.N., Eg o rova T.A., Panin I.G., G rechishnikov V.V., Panin A.I., S e rgachev P.A., Ryasnoi P.V., Afanas'ev V.A. Rukovodstvo po optimizatsii retseptov kombikormov dlya sel'skokhozyaistvennoi ptitsy [Optimized ingredients of combined fodder for poultry: manual guide]. Sergiev Posad, 2014: 151.

46. Roth-Maier D.A., Kirchgessne r M. Feeding of 00-rape seed to fattening chickens and laying hens. Archiv für Geflügelkunde, 1995, 59: 241-246.

47. Akkulic M. Etlik civiciv rasyonlarina degisik duzey lerde katilan colza tohumu kuspesi ile ham ve rafine kolza yagimin candi agireik artisi, yem turetimi uzerine etkisi. Ankar. Univ. veter. fak. Derg, 1982, 29(1/2): 23-40.

48. B a n a s z k i e wi c z T. Nutritive value of rapeseed 00 and oil for chickens. Biul. Nauk. Przem. Pasz., 1995, 1: 43-54.

49. L o s h k m o i n i k v I.A. V sbornike: Kormovye resursy Zapadnoi Sibiri i ikh ratsional'noe ispol'zovanie [In: Fodder resources of Western Siberia and their use]. Omsk, 2005: 146-150.

50. Lo sh k mo in ik o I.A. V sbornike: Ratsional'noe ispol'zovanie kormovykh resursov i geneticheskogo potentsiala sel'skokhozyaistvennykh zhivotnykh [In: Effective use of fodder resources and farm animal genetic potential]. Omsk, 2004: 79-83.

51. Gheis a ri A., Ghayor P. Different dietary levels of rapeseed meal effects on egg quality characteristics in indigenous breeding hens. Journal of Farm Animal Nutrition and Physiology, 2014, 9/1(1): 1-8.

52. Taraz Z., J a la li S.M.A., R a f e i e F. Effects of replacement of soybean meal with rapoeseed meal on organs weight, some blood biochemical parameters and performance of broiler chicks. Int. J. Poult. Sci., 2006, 5: 1110-1115.

53. Tadelle D., Ale mu Y., Moge s H.M., Fas il K. Effect of level of rapeseed (Brassica carinata) cake in rations on broiler performance. Livestock Research for Rural Development, 2003, 15(4): 1-5. 
54. Ispol'zovanie rapsovykh kormov v ptitsevodstve: Metodicheskie rekomendatsii /Pod redaktsiei V.I. Fisinina, I.A. Egorova [Rapeseed containing feed in poultry: guidelines. V.I. Fisinin, I.A. Egorov (eds.).] Zagorsk, 1990: 23.

55. Riyazi S., Ebrahimnezhad Y., Nazeradl K., Maheri-Sis N., Salamatdust R., Vahdatpour T. The effects of replacing soybean meal with different levels of rapeseed meal on egg quality characteristics of commercial laying hens. Asian Journal of Animal and Veterinary Advances, 2009, 4: 337-341 (doi: 10.3923/ajava.2009.337.341).

56. B a n a z z i e wi c z T. Effect of xylanase application to rapeseed cake diet on digestibility and deposition of nutrients and energy in young broiler chickens. World Journal of Veterinary Science, 2013, 1: 18-24 (doi: 10.12970/2310-0796.2013.01.01.4).

57. $\mathrm{S} h \mathrm{p}$ a k ov A.S., F irts e v A.I., G a ga n ov A.P. Ispol'zovanie rapsa v kormlenii sel'skokhozyaistvennykh zhivotnykh: Rekomendatsii [Rapeseed in the diet of farm animals: recommendations]. Moscow, 2004: 10-33.

58. F a l a le e va E.V. Vyrashchivanie tsyplyat-broilerov pri ispol'zovanii v kormosmesyakh rapsovogo zhmykha. Avtoreferat kandidatskoi dissertatsii [The use of rapeseed cake in the diet of growing broiler chicks. PhD Thesis]. Omsk, 2005.

59. L e n k ova T.N., E g o rova T.A. V sbornike: Nauchnye trudy VNITIP [In: Scholarly articles of All-Russian Research and Technological Institute of Poultry]. Sergiev Posad, 2012: 49-55.

60. Kaposius M., Danus S., Gruzauskas R., Sasyte V. Veterinarija ir zootechnika, 2001, 13(35): 71-74.

61. B e 11 J.M. Factors affecting the nutritional value of canola meal: a review. Can. J. Anim. Sci., 1993, 73: 679-697.

62. Kermanshahi H., Abbasi Pour A.R. Replacement value of soybean meal with rapeseed meal supplemented with or without a dietary NSP-degrading enzyme on performance, carcass traits and thyroid hormones of broiler chickens. Int. J. Poult. Sci., 2006, 5: 932-937.

63. Z e b A., S a t t a r A., Me u le $\mathrm{n} \mathrm{U}$. Effect of feeding different levels of rapeseed meal on the performance of broiler chicks. Arch. Geflugelk, 1999, 63: 77-81.

64. Janjecic Z., Grbeša D., Muzi c S., Curic S., Rupic V., Liker B., Dikic M., Antunovic B., Zupanic D. Influence of rapeseed meal on productivity and health of broiler chicks. Acta Vet. Hung., 2002, 50: 37-50.

65. Choct M. Enzymes for the feed industry: past, present and future. World's Poult. Sci. J., 2006, 62(1): 5-15 (doi: 10.1079/WPS200480).

66. Kocher A., Choct M., Porter M.D., Broz J. The effect of enzyme addition to broiler diets containing high concentrations of canola or sunflower meal. Poult. Sci., 2000, 79: $1767-1774$.

67. Banaszkiewicz T., B orkowska K., Kot B. Effect of high rape cake content supplemented in enzymes on the nutritional value of a broiler diet and intesninal lactic acid bacteria number. Acta Veterinaria, 2009, (5-6): 535-545 (doi: 10.2298/AVB0906535B).

68. Le nkova T., Egorova T., Svitkin V., Men'shinin I., Kurmanaeva V. Kombikorma, 2013, 6: 86-88.

69. Le nkova T.N., Svitkin V.S., Egorova T.A. Combined feeds for broilers containing triticale grain. Vestnik OrelGau, 2013, 6: 76-80.

70. Chess o n A. Non-starch polysaccharide degrading enzymes in poultry diets: influence of ingredients on the selection of activities. World's Poult. Sci. J., 2001, 57(3): 251-263 (doi: 10.1079/WPS20010018).

71. Kocher A., Choct M., Morrisroe L., Broz J. Effect of enzyme supplementation on the replacement value of canola meal for soybean meal in broiler diets. Aust. J. Agric. Res., 2001, 52: 447-452.

72. L e n k ov a T.N., Eg o r o va T.A. Ptakhivnitstvo (Mezhvidomchii tematichnii naukovii zbirnik) [Poultry farming: collected articles. Issue 68]. Alushta, 2012, vypusk 68: 281-283.

73. Titov V., Le nkova T., Egorova T., A ntipov A. Influence of 00-rapeseed cake on broiler productivity and the thyroid gland condition. Proc. XIV Eur. Poultry Conf. Stavanger, Norway, 2014: 534.

74. Le n k ova T., Egorova T. Ptitsa i ptitseprodukty, 2011, 2: 49-51.

75. Le n k ova T.N., Eg o rova T.A Ptitsevodstvo, 2011, 4: 37-40.

76. Le nkova T.N., Eg o rova T.A. Materialy Mezhdunarodnoi konferentsii «Kombikorma2012: Sovremennoe proizvodstvo kombikormov» [Proc. Int. Conf. «Combined fodder-2012: advanced feed production». Moscow, 2012: 145-146. 